\title{
Epistemology and social work: Integrating theory, research and practice through philosophical pragmatism
}

\author{
Steve Hothersall ${ }^{1}$
}

\begin{abstract}
Debates regarding theory and practice in social work have often avoided detailed discussion regarding the nature of knowledge itself and the various ways this can be created. As a result, positivistic conceptions of knowledge are still assumed by many to be axiomatic, such that context-dependent and practitioner-oriented approaches to knowledge creation and use are assumed to lack epistemological rigor and credibility. By drawing on epistemology, this theoretical paper outlines the case for a renewed approach to knowledge definition, creation and use within social work by reference to pragmatism. Pragmatism has the potential to act as an organizing theoretical framework, taking account of the role of both ontology and epistemology, acting as a functional methodology for the further enhancement of practice-based knowledge.
\end{abstract}

Keywords: knowledge; epistemology; ontology; pragmatism; social work; practice; evidence

1. Head of Social Work Education

Address for correspondence: Faculty of Health and Social Care - Social Work, Edge Hill University, St Helens Road Ormskirk L39 4QP. Hotherss@edgehill.ac.uk

Date of first (online) publication: 


\section{Introduction}

A perennial debate in the history of social work (Soydan 1999; Payne 2005) is that of the relationship between theory and practice and by what means and in what ways these domains do, do not, should, or should not influence each other (Bernard-Donals 1998; Witkin 2011; Salisbury Forum Group 2011; Wiley 2012; Julkunen, Austin, Fisher and Uggerhøj 2014). This (somewhat circular) debate is essentially about the issue of knowledge of and for social work (and arguably, similar professions, although this paper will focus solely on social work), although there is little evidence of sustained and critical discussion regarding the epistemological basis of and for such knowledge: what knowledge actually is and how it is created. In addition, there is little commentary on the relationship between epistemological principles and processes and the nature of social life - the connection between epistemology and ontology - that which is, which influences how knowledge is used, developed and disseminated.

In this theoretical paper I will draw on the cognate discipline of philosophy and the sub-disciplines of epistemology and (social) ontology to present an illustrative account of the development and use of knowledge within social work, drawing on a range of materials from the UK, the USA, Central Europe, Australasia and the Scandinavian countries. However, such an approach does not claim to provide a definitive historical account of the epistemological dénouement of social work; rather, the intention is to provide the reader with a sense of the different positions and 'leanings' social work has taken during its evolution with regards to its engagement (or not) with epistemological principles and how these have 'played out' within the context of practice and within the 'academy'. The aim is to illustrate how these issues might now benefit from being viewed through a different philosophical 'lens' - that of (philosophical) Pragmatism (Peirce 1905; James 1977; Dewey 1929, 1938; Almeder 2007; Rescher 2008; Bernstein 2010), which could provide a framework to allow for the fullest use of the broadest range of differing forms of knowledge and knowing (Gibbons et al 1994; Gibbons 2000), so as to equip the profession more readily with 'functioning practices' (Julkunen and Karvinen-Niinikoski 2014: 1).

The engagement with a specifically Pragmatic epistemology has the added potential to refocus the knowledge debate and integrate what many see as disparate (and divisive) approaches regarding which forms and types of knowledge are 'best' for the profession (Ulrich 2007; Goldenberg 2009). In formulating the present approach, the perceived 'theory and practice' dichotomy could be narrowed (Witkin 2011) and the confidence of practitioners in relation to their understanding, use and development of theory of, for and from practice significantly enhanced, particularly if practice is conceived more dynamically as praxis (Flyveberg 2001; Kinsella and Pitman 2012; Petersén and Olson 2014).

This project though is more than a simple 'recommendation' to think differently. Pragmatism is more than just an approach to understanding knowledge and how 
it is created (in the guise of an epistemology) - it also has something to say about ontology, as it fully acknowledges the mind-independent reality we all experience in the form of a priori knowledge - that the mind and the world are co-constituted and as such, Pragmatism has much to commend it as a social theory of action (Pratt 2016), with many similarities to Bhaskar's Critical Realist perspective (Bhaskar 1975/2008, 1979), although the latter would contend that knowledge (epistemology) must conform to the structures of the world ('heavy' ontology), rather than more moderate positions that recognise the role of perception and meaning-making in relation to ontological commitment ('moderate' ontology) (Searle 1998). We therefore have the potential for a more informed engagement with both epistemology and (social) ontology (Epstein 2016; Tuomela 2013; Kaidesoja 2013). Rescher (1994) is clear on the relevance of philosophy to the practicalities inherent within the human condition, a core component of the profession of social work:

Philosophy seeks to bring rational order, system, and intelligibility to the confusing diversity of our cognitive affairs. It strives for orderly arrangements in the cognitive sphere that will enable us to find our way about in the world in an effective and satisfying way. Philosophy is indeed a venture in theorising, but one whose rationale is entirely practical. (p5)

Philosophy in its variegated practical forms has already achieved significant traction within social work and many other professions through the application of a range of principles taken from moral philosophy. For example, writers such as Banks (2014) and Hugman (2013) have harnessed axiological tenets derived from Aristotle, Kant and others to develop a professional discourse relating to values and ethics. In much the same way, Garrett (for example 2015, 2011, 2009, 2007a, 2007b) has utilised aspects of the works of other philosophers to energise a critical sociology focusing on the profession, highlighting the works of Wacquant, Rancière, Badiou, Bauman, Gramsci, Marx and Bourdieu amongst others, driving forward the theoretical (Garrett 2013) in an attempt to inform the practical. Others are of course thinking and writing in similar ways (e.g. Heinsch, Gray and Sharland 2015; Gray and Webb 2013), with a number of writers from the Scandinavian countries focusing on the development of 'practice research' through more contextually and ontologically-engaged methodologies (Kivinen and Piiroinen 2004; Mäntysaari, 2005; Alexanderson et al 2009; Bailey 2014; Harrikari, Rauhaka and Virokannas 2014; Høgsbro 2015), reflecting the ongoing development of the importance of practice-based research at an international level (Epstein et al 2015; Julkunen, Austin, Fisher and Uggerhøj 2014; Julkunen and Karvinen-Niinikoski 2014; Salisbury Forum Group 2011). That said, the 'philosophical' in social work is still somewhat underrated and still somewhat 'maligned' (Grimwood 2013): this paper therefore is also a small contribution to the furtherance of the development of practical philosophy in social work, with particular emphasis on the epistemological discourse. 


\section{An introduction to epistemology}

In order to set the scene for the commentary and discussions that follow, it is necessary to engage in some 'philosophizing' so as to clarify our terms of reference. As a discipline, epistemology is driven by a number of basic but highly significant questions, and is primarily concerned with evaluating claims about the way the world can be known to us (Audi 2011; Pritchard 2009). It asks: What is knowledge? What can we know? How do we know? And what are the means by which we demonstrate this knowledge as knowledge to others? It provides an account of a range of principles and mechanisms that offer a clear, logical account of the processes involved in the creation, use and validation of knowledge forms, irrespective of the particular methodological approach adopted or the source of such knowledge. In this paper, I shall also consider the relevance of three particular epistemological principles that can assist us in understanding more readily the relevance of epistemology for professional social work practice:

1. the need for some underpinning or 'foundational' beliefs to exist in order to act as a basis for the creation of knowledge (foundationalism) (Weinberg 2015);

2. the claim that all knowledge is provisional, indeterminate and therefore fallible (fallibilism) (Hannon 2014) and

3. that knowledge is related to its context (contextualism) (Medina 2004; Pynn 2015).

Epistemology therefore embraces a number of issues: the very possibility of knowledge itself - what is it? what are the limits of our knowledge - are some things unknowable? Where does knowledge come from - the senses, experience or both? Is it a priori and therefore innate? How best to obtain knowledge - by deduction, induction, abduction or intuition? And what is the relationship, if any, between the subjective and objective components of knowledge, and what forms of truth exist - is it intrinsic? Is truth that which corresponds to reality, or is it that which is coherent with our understanding of reality, or is there some consensual position to be achieved? (Blackburn 2006). As these issues have evolved, we now have a much more differentiated view of knowledge as taking distinct forms: self-knowledge; common sense or tacit knowledge; everyday knowledge; wisdom and scientific knowledge. In relation to the latter, scientific knowledge is invariably (and narrowly) categorised as comprising deductive and inductive knowledge forms.

All of these considerations however relate to another aspect of philosophy: ontology - the theory of being and the nature of reality itself. Any knowledge that we have is knowledge of or about reality; thus, the ontological dimension is that which is explored and articulated via the processes of inquiry. Inquiry into both the natural and the social worlds has evolved into distinct approaches with distinct methodologies and underpinning ideologies, and to some extent this divergence 
has been necessary and wholly appropriate. The exploration of the physical world has necessitated strict observations, measurement, calculation and description in order that predictions can be made, and on the basis of these, inferences regarding causality made with (often) an impressive degree of precision. These developments, ideological or paradigmatic subtleties aside, have led to huge benefits. Science (in the positivistic tradition) has done us proud and the benefits of the application of the 'scientific method' and its deductive logic are to be celebrated. The nature of the physical world is better understood than ever before and all of us benefit from this. In that regard, criticism of the positivistic, hypothetico-deductive approach (Bayes and Price 1763; Popper 1935/2002a; Hempel 1966) need to be tempered and located correctly in relation to its stated purpose and context. The 'science wars' arose as it became more and more apparent that the methodologies of the natural and physical sciences were less and less applicable to the study of the social world. Thus, whilst criticisms are justified in this context, they should in no way be taken to imply a disregard of the importance of these approaches in other respects - hence criticism needs to be situated in the relevant socio-historical context (see Nietzsche 1913/1996).

So, let us now try to understand what we mean when we talk about knowledge. What is it? The traditional or 'classic' account (Ayer 1963) is that knowledge is a proposition (a statement or 'fact' about something) that functions as a belief deemed to be true and justified (i.e. supported by evidence of some sort - a justified true belief - JTB). This is usually taken to refer to propositional knowledge or 'knowing that' (KT) as distinct from intuition, tacit, or practice-based knowledge, generally referred to as 'knowing how' (KH). These propositions usually take the form of 'knowledge that $p$ ', where $p$ is an indicative sentence (for example 'Elephants do not fly') (Zagzebski 1999). The latter form of knowledge $[\mathrm{KH}]$ is variously described as practice, tacit or craft knowledge, knowing both what to do and how to do it, and is therefore very much about knowledge in action or skill (Ryle 1949; Schön 1983). These forms are often seen in 'either/or' terms (or quite often as 'either/or not-at-all'), rather than as being part of the same thing - equally viable and valid means of knowledge creation. In the same way as we cannot appreciate what it is like to feel sad unless we have felt happy, so seeing KT as being separate and distinct from $\mathrm{KH}$ means that neither has much meaning on its own: they are complementary. This 'either/ or (not-at-all)' attitude and the differences they tend to exemplify represent dogma concerning the alleged preeminence of propositional knowledge forms, 'ideally' derived from scientific or positivistic methods, a view clearly still pervasive today (Greenhalgh et al 2016). These approaches are seen by some to provide a vocabulary where 'the language of goals, objectives, outcomes and effectiveness challenges the reliance on sentimentality, opinion-based practice, intuition or lay-knowledge.' (Shaw 1992: 42). These stand in stark contrast to other forms of knowledge and knowing derived from more interpretivisitic, action-oriented and phronetic approaches (Skaerbaek 2010; Goldenberg 2009; Petersén and Olsson 2014), including the exercise and 
application of professional 'expertise' often based on intuition and tacit knowledge and often derived from experience and practice (Dreyfus and Dreyfus 1986; Fook, Ryan and Hawkins 2000; Edwards and Daniels 2012).

However, a seminal paper by Edmund Gettier (1963) asked the deceptively simple question 'Is justified true belief knowledge?' It appears that the answer to that question was (and still is) 'no'. As a result, Gettier problems now refer to situations where a proposition, functioning as a belief thought to be true and justified, does not in fact count as knowledge on the classic account previously referred to, although the individual concerned is unaware of this. The claim that 'All Swan's are White' is perhaps the most familiar example (Taleb 2011), as until a black swan was discovered, we were 'safe' in the 'knowledge' that all swans were white - a clear example of a Gettier-type objection to claims about knowledge.

Gettier's claim that JTB is not in itself sufficient for claiming that we possess knowledge has perhaps provided an opening for the acceptance of the role, function, significance, relevance and utility of other forms of knowledge and knowing, including highlighting the significance of broader considerations relating to the foundations of our knowledge, its inherent fallibility and the relevance of context. It is therefore permissible to contend that this is in fact the case, and argue that by reference to a pragmatic epistemology (Peirce 1905; Comesaña 2013) and recourse to the integrative elements of Aristotelian philosophy concerning episteme, techne and phronesis (Flyvebjerg 2001), we can effectively accommodate Gettier's objections and normalize them (Kelp 2016; Turri 2015; Church 2013). Here, Rescher (2008) provides a helpful means of addressing the Gettier conundrum from a pragmatist perspective by referring to knowledge as being predicated upon the application of justified presumptive beliefs (JPB), rather than upon justified true beliefs (JTB):

Presumptively justified beliefs are entitled to remain in place until displaced by something better. Accordingly, their impetus averts the dire consequences that would ensue if any and every cogent process of rational deliberation required inputs which themselves had to be authenticated by a prior process of rational deliberation, in which case the whole process would never get under way. (Rescher 2008 pp394-395)

We can therefore act on the basis of such (presumptively held) beliefs and engage with the external (ontological) world and its challenges without worrying or being unnecessarily affected by the regress problem (Wiley 2012; Hume 1748/2008; Lange 2008; Howson 2000; Schlagel 1984). A JPB allows us to act with reasonable confidence that our belief is true unless and until information to the contrary becomes available, assuming we are both willing and able to revise our claims as new information becomes available or new insights emerge. Lipton (2004) and Goldstein (2011) amongst others follow similar paths when they refer to Inference to the Best Explanation (IBE), itself another way to frame the principles espoused by the pragmatic maxim discussed below. The essence of such pragmatic epistemic 
activity is to be found in the processes of reflection, already a core (and, some would say, a foundational) activity within social work, and one that mirrors the elements of phronesis as a form of knowledge creation and research activity (Thomas 2010; Flyvbjerg, Landman and Schram 2012). Phronesis refers to the practice of science (or inquiry) undertaken by reference to context, practical rationality, judgement and experience - a 'bottom-up' approach to scientific endeavour (Uggerhøj 2011).

In terms of the relevance of Gettier-type problems to social work and other forms of practice, consider the situation where a social work practitioner believes that a child has been harmed by its parent and takes action on this basis (removal). There may be no justification for the belief under the 'classic' account of knowledge, as the extant truth-value may not have been verified, and yet action is still taken because not to do so would be irresponsible, given what the practitioner thinks they know at the time. Technically, the actions of the practitioner are, under the 'classic' account, based on something other than knowledge, and yet this course of action is understandable as a response. Gettier's account is more pragmatic and accommodating to what actually happens - and needs to happen - in real life. We all operate on the basis of what we think or regard as knowledge at the time, ceteris paribus. By responding to Gettier's objections regarding JTB pragmatically, we can accommodate to them quite effectively, even though we cannot 'solve' them, as many have tried to do (Turri 2011). Gettier problems are only problems in relation to the 'classic' JTB account of knowledge, which had historically defined the prevailing discourse within epistemology.

\section{Foundational beliefs}

Issues of how particular forms of knowledge $(\mathrm{KT} / \mathrm{KH})$ come into being in the first place and the 'status' they have raises a number of questions relating to the 'foundations' upon which knowledge is based. The notion of foundational beliefs has an important role in professional practice and social life more generally (Kempson 1975; Fish 1989). Wittgenstein (1969) in 'On Certainty' [OC] claims that we have a number of 'background' beliefs that are so fundamental to our ontology and our very being, that we are unable to question them, providing us with a fixed point of reference. He states: 'T have a world picture. Is it true or false? Above all it is the substratum of all my enquiring and asserting' (OC: para 162) and 'The questions that we raise and our doubts depend upon the fact that some propositions are exempt from doubt, are as it were like hinges upon which those turn' (OC: para 341). Hume (1748/2008 85.1) phrases it somewhat differently but refers to the same necessity when he says, '... without the influence of custom we would be entirely ignorant of every matter of fact beyond what is immediately present to the memory and senses.' This 'foundationalism' is a necessary part of the discussion concerning forms of professional knowledge (Baars 2010; 
Shields 2003) and resonates with Dewey's (1922) notion of 'habit' and Bourdieu's concept of 'habitus' (Bourdieu 1977: 78) as precursors and contextual elements in knowledge-making processes. In this context however, the epistemological construct of 'foundationalism' should be regarded as pluralistic in order to negate the argument about whether knowledge of $\mathrm{X}$ is more important than knowledge of $\mathrm{Y}$, given the increasing move towards interdisciplinary practice and education (Uggerhøj 2014; Fook et al 2013; Hood 2012).

Perhaps one way to (re-) conceptualise the issue of foundationalism is to revisit and reflect upon Stevenson's idea of putting knowledge into a 'frame' (of reference) rather than seeing it as a 'body of knowledge' (Stevenson 1971) which implies that it is in some senses, fixed. As Stevenson aptly notes, '...to try and build a social work house on the shifting sands of social science theory is asking for trouble'. (Ibid: 226). This position more accurately reflects the idea that knowledge is both constructed and re-constructed as required, dependent on circumstance, context and a range of other factors. The notion of a knowledge base also implies that there is some knowledge that social work cannot do without, whereas a knowledge bias, as suggested by Payne (2001) reflects rather a leaning towards some particular theoretical construction. As Payne (2001: 145) notes

the role of knowledge within social sciences is more of a process of social construction than the establishment of irrefutable and universal laws of social behaviour..

By accepting this position, we can assert a non-essentialist view of foundationalism that provides the rationale for the view that whilst all statements and knowledge claims may well have a right to enter the public discourse with the possibility of representing a viable alternative (the principle of non-uniqueness), not all have legitimacy and credibility. Simply put, some beliefs may be silly and/or outlive their usefulness, and therefore will not gain any traction whatsoever (the principle of cognitive egalitarianism) (Laudan 1990). However, those that do conform to the 'rules' - or the context of use, will at least be considered relevant, even though they may not ultimately be accepted in their original form. In this way, foundational beliefs are not fixed, but changeable, reflecting the interface between ontology and epistemology to represent the nature of the world as we understand it.

Such an interpretation of 'foundationalism' is a necessary part of the discussion concerning the types and forms of professional knowledge, important in that it allows us to consider the manner in which people (agents) from different epistemic communities (professional groupings) and with different epistemological beliefs (claims to possessing knowledge) are able to act (Uggerhøj 2014), as well as reflecting, somewhat prospectively in the hands of Hume, the emergence of the contemporary view that we all develop and use 'schemas' (Piaget 1953) heuristically. The notion of strict foundationalism within the philosophical canon refers to and represents a degree of fixity and infallibility regarding our beliefs, which neither Wittgenstein, 
Hume, Dewey (1929a), nor Bourdieu (1977) for that matter, intended, in spite of the dangers inherent within what Bourdieu refers to as the 'doxa' - those taken for granted assumptions about the world and our place in it that can have a somewhat ossifying effect (Eagleton and Bourdieu 1992). These non-essentialist conceptions do not support a strict foundationalism; rather, they assert that in order to prevent the dissolution of all our beliefs (and therefore our actions in and upon the world) into complete scepticism and doubt, we rely on a series of background assumptions that provide us with a fallible and therefore a revisable frame of reference based on our engagement with the world and that which we already know of it.

\section{Fallibilism}

The acceptance of a proposition qua knowledge in the context of practice or any other day-to-day activity for that matter has to take account of the Duhem/ Quine Thesis (Duhem 1954; Quine 1960) which states that the evidence will always underdetermine theoretical formulations (the 'facts') as, following Hume (1748/2008), there is no amount of data that can ever constitute a theoretical or any other form of conclusion in an absolute sense. All findings and subsequent theoretical constructs (and therefore knowledge) are, by definition, ambiguous, provisional, fallible (Vahid 2005; Hannon 2008) and open to revision. What this means is that any knowledge, and from a practice-perspective as mentioned earlier, actions predicated on this, even if derived from the most authoritative and 'scientific' of sources, cannot be taken to be definitive. This implies that knowledge generated in situ and from practical experience has just as much (or just as little) validity as that derived from other context-independent sources, ceteris paribus. All forms of knowing depend for their overall validity on the extent to which they adhere to epistemic principles and their relevance to the person(s) concerned. These principles are arguably central to the practice of social work itself because of their importance in establishing the viability of our beliefs as knowledge forms that are functional within particular situations and contexts at particular times (Fantl and McGrath 2009) - context-dependence.

In the absence of assured knowledge, we must therefore accept the (uncomfortable) presence of circular reasoning or infinite regress (Hume 1748) because of the limitations inherent within epistemology. From such a position, these represent, respectively, the claims of deductive versus inductive approaches to inference and reasoning, although they should not necessarily be assumed to be arguments from 'antiquity' as current debates in the field of quantum theory recognise similar tensions:

If quantum theory encourages us to keep fluid our conception of what is reasonable, it also encourages us to recognise that there is no universal epistemology, no single sovereign way in which we may hope to gain all knowledge...There is a kind of 
epistemological circle: how we know an entity must conform to the nature of that entity; the nature of the entity is revealed through what we know about it. There can be no escape from this delicate circularity. (Polkinghorne 2002: 87)

Our search for a strict and absolute foundationalism and its associated certainty in the philosophy of science and ultimately, in and across all forms of social life, is in essence an attempt to resolve (or at least respond to) Hume's (famous) 'problem of induction', even though Aristotle and others had noted its presence much earlier. However, it was in A Treatise of Human Nature (Book 1, part iii, §6 - 'Of the inference from the impression to the idea') and later in 1748 in 'An Enquiry Concerning Human Understanding' (Siv - 'Sceptical doubts concerning the operations of the understanding') that Hume first articulated his powerful and classic formulation that now has the status of a philosophical 'classic'. As a result, inductive reasoning remains '...the glory of science' and '... the scandal of philosophy' (Broad 1952: 143). The essence of the problem of induction is that our opinions regarding what we have not observed have no justification at all and never will have (on the 'strong' interpretation of Hume - although see Schlagel 1984). On this basis, Hume's assertion has the potential to deny epistemic credibility to every product of science and to every effort of common sense. Thus, rather than referring to knowledge as foundational, it should be regarded as being relevant and necessary, at that time, and in that place.

\section{Contextualism}

One of the key features of the knowledge debate is the extent to which context plays a part. Contextualism is based on the context-sensitivity of knowledge claims. In philosophical circles, instances of ' $S$ knows that $p$ ' (where $S$ is a subject and $p$ some proposition) express different propositions and have different truth conditions in different contexts (McKenna 2015). Thus, a claim that 'S knows that the patient has condition $\mathrm{X}$ ' is, ceteris paribus, likely to be treated differently when made by a medical practitioner as opposed to an electrician. Furthermore, the extent to which a knowledge claim can be seen to be acceptable also depends upon the knowledge standards operative in the particular knowledge context, which are themselves determined by various features of the context itself. For example, a claim that ' $S$ knows that the purse was in the bag' will vary in terms of its acceptability and, ergo, its perceived validity when uttered as $S$ is leaving the house to go shopping as opposed to being uttered in the witness box in a criminal case at the Old Bailey (Brown 2015). Thus, the knowledge (epistemic) standards for knowledge claims are on a continuum and vary as a function of the (perceived) attributes of the person making the claim and the situation within which the claim is being made (Stanley 2007). For Pynn (2015: 29) '... the truth conditions of knowledge claims vary with the epistemic standards of the context of utterance.' 
As a result, contextualism can provide a counter against the worst features of relativism and the descent into (absolute) skepticism, (Grayling 2009) whereby the truth-value of any claim is almost irrelevant to any contextual, situational or other epistemic variable (Harth 2014). Such a position could lead to an absolute relativist construction of the world where almost 'anything goes', negating the role of context or any other variable as a mediating and stabilizing factor. Blumer (1969) however reminds us that a definite sense of perspective regarding the social constructionist view is important, because a view that holds that knowledge (or any aspect of the social world) is socially constructed

... does not shift 'reality', as so many conclude, from the empirical world to the realm of imagery and conception... [The] empirical world can 'talk back' to our picture of it or assertions about it - talk back in the sense of challenging and resisting, or not bending to, our images or conceptions of it. This resistance gives the empirical world an obdurate character that is the mark of reality. (p22)

This should remind us that there is, and has to be, an almost symbiotic relationship between ontology and epistemology - as Searle (1995) notes, so called 'social facts', generated as part of our understanding and interpretation of the world (the ontological dimension and represented to us internally as knowledge of the world through our individual epistemology) are ontologically subjective but epistemologically objective:

... it could not be the case, as some have maintained, that all facts are institutional [i.e., social] facts [epistemological]; that there are no brute facts [ontological], because the structure of institutional facts reveals that they are logically dependent on brute facts. To suppose that all facts are institutional [i.e., social] would produce an infinite regress or circularity in the account of institutional facts. In order that some facts are institutional, there must be other facts that are brute [i.e., physical, biological, natural]. This is the consequence of the logical structure of institutional facts.' (62.) [emphasis and additional parentheses mine].

Within the realms of professional practice, contemporary ecological models are one illustration of the importance attached to the influence of context by many writers including Bronfenbrenner (1979), Mullaly (2007), Wormer (2007), Jack (2012), Gitterman and Germain (2013), Manfredo et al (2014), Payne (2014) and Simplican et al (2015) all of whom explicitly acknowledge the influence exerted on individuals by their environments and how practices are mediated by reference to these. The importance of the influence of context on people's lives has also been translated into practice-based guidance in numerous guises, perhaps most readily illustrated by the 'Common Assessment Framework' and its variants across the UK (Author's own 2014). Thus, although context is widely seen as important as a 
mediating variable in practice domains, it has yet to permeate the knowledge debate with the same resonance in terms of its relationship to research. However, this trend is now changing somewhat, although it is still perhaps moot as to what extent an explicit engagement with epistemology, taking account of the three epistemological principles referred to above: foundationalism, fallibilism and contextualism, can be easily and readily discerned.

\section{A brief survey of the 'epistemological' in social work}

It is perhaps Flexner (1915/2001), in the context of the Addams/Robertson debacle in the late $19^{\text {th }}$ century regarding the best way to 'do' social work, in some ways a precursor to similar discussions in the contemporary literature (Franklin 1986), who can be 'credited' with damaging social works' reputation as a profession because it did not/could not evidence a clear and credible knowledge base, citing medicine as the 'standard bearer' for such (Lorenz 2012; Gilgun and Adams 2002; Soydan 1999). This view, based upon claims that 'scientific' (qua positivistic) approaches to knowledge creation were/are better than other approaches is still espoused by some who suggest that 'Social work tends to be an incoherent set of theories and techniques without a systematic structure' (Göppner \& Hämäläinen 2007 p280). Largely as a result of such comments and the view that

With its claims to validity, science supplies assured factual and explanatory knowledge for the substantiation or guidance of professional action.' (Gredig and Sommerfeld 2008 p292: emphasis mine)

and the writings of Etzioni (1969) for example, social work has spent the last few decades trying to justify its existence, not just in terms of professional identity and epistemological status, but also in terms of its efficacy within a post-modern newworld order (Leonard 1997; Rodger 2000; Lorenz 2006; Slater 2012).

The need for social work to utilise and refer to relevant knowledge is however unquestionable, all the more so when the activities of a particular occupational group may be such as to involve life and death decisions; in cases of serious child abuse for example (Laming 2003: 2009; Devaney, Lazenblatt and Bunting 2011), decisions to detain people against their wishes as in the case of the care and treatment of those individuals with a mental disorder or those affected by a range of disabling conditions making them vulnerable to harm and exploitation (Shaw 2016; Herring 2016; Author's own 2010, 2011). Howe (1980) notes that with its '... yearnings which it has for professional recognition, social work has found itself looking for a distinctive and convincing body of knowledge' (p319) to the extent that it appears to hang on to everything it develops, thereby presenting with a rather 'swollen' and 
'congested' knowledge base, perhaps representing nothing more than '...the steady accumulation of unrelated relics' (Ibid) for which he suggests there may be three possible explanations. Following Kant,

... if it is impossible to produce unanimity among those engaged in the same work, as to the manner in which their common objective should be accomplished, then we may be convinced that such a study is far from having attained the secure course of a science, but is merely a groping in the dark. (Kant 1787/2007 in Howe 1980 p13)

Thus, being unable to agree on what to do does little to clarify how it should be done.

These apparent 'failures' of social work in terms of behavioural and social change (although see Briggs and Briggs 2016) and the use of codified propositional knowledge (KT) to the apparent exclusion or derogation of other forms of knowing perhaps supports what Grace and Wilkinson (1978) claimed, namely that 'The nature of social work knowledge is not to be found in the literature, but 'in situ" (p322). This clearly refers to the use of knowledge derived in and from practice (Houston 2010; Kjørstad 2008; Mitchell, Shaw and Lunt 2008; Curnock and Hardiker 1979) emphasising the importance of how social worker's do what they do, an additional type of knowledge: 'knowing how' $(\mathrm{KH})$. Some writers note however that the apparent lack of theory use by social workers in situ (Carew 1979) may well have something to do with the perceived 'inadequacies' of the theories themselves. Rosen (1994) in his writings states that

... effective and accountable practice will be enhanced through focused efforts to develop scientifically valid and practice-relevant knowledge and through appropriate use of such knowledge in making practice decisions. (p561)

His findings (Rosen 1994) suggest that social workers are poor at being able to identify and articulate the knowledge they actually use in practice (which is distinct from them not actually using any), and he suggests that the structure of knowledge itself may be an impediment to its effective use in practice:

To be useful professionally, theoretical or empirical generalisations need to be applicable beyond the specific instances (cases or study samples) on which they are based...Thus, the very feature that renders knowledge statements professionally worthy (their generalisability) may be an obstacle to their use by practitioners in a specific practice situation. (Rosen 1994 pp562-3)

This is a fairly clear statement to the effect that attempts to apply knowledge generated through the methodologies of the natural sciences end up losing their relevance in the very act of application, the dilemma of the '...idiographic application of normative generalisations'. (p562). This is, in essence, a restatement of Hume's 
paradox concerning induction and still very much a 'live' issue in today's debates regarding evidence-based practice (for example, Gambrill 2013; Evans and Hardy 2010; Sheldon 2001; Webb 2001).

These concerns regarding the type of knowledge of and for social work have been around for many years as the citations above attest to. Their inclusion does not imply a 'dated' literature search, but rather an attempt to highlight the longevity of the concerns regarding epistemology within professional social work, which has generally been somewhat overlooked, although there are some exceptions to this general trend. The work of Michael Sheppard (Sheppard 1995, 1998) and his collaborators (Sheppard and Ryan 2003) provide a number of thoughtful and quite sophisticated accounts of the role of differing modes of reasoning and how these act as mechanisms by which differing forms of knowledge can be generated. His discussions of inductive, deductive and abductive reasoning ('thinking backwards'), and those of others with a more specific focus on this (Haig 2008; Shank 1998; Znaniecki 1934) take us some way down the epistemological road. Other writers have also contributed meaningfully to the discussions regarding knowledge in social work (Parton 1996, 1998, 2000; Jordan and Drakeford 2012; Gray and Schubert 2012, 2013; and Webb 2001), but whilst also exploring the importance of knowledge within the profession, do so more generally, avoiding any detailed discussion of epistemological principles per se.

These discussions also relate to the issue of how knowledge becomes accepted and articulated in the first place. Particular types of knowledge have historically been more privileged over others, their underlying methodological and ideological structures generating what Foucault (1974) refers to as 'regimes of truth'. These are located within the broad 'episteme', which itself comprises (amongst other things)

... the totality of relations that can be discovered, for a given period, between the sciences when one analyses them at the level of discursive regularities.' (Philp 1979: 191)

A contemporary example of this is evidence-based practice (Soydan and Palinkas 2015; Webb 2001) and the recent knowledge and skill 'statements' (DfE 2014, DH 2014). Although Philp makes particular reference to Marxist forms of knowledge, he makes the more general point that epistemological idealism fails to take account of the influence of broader issues regarding what social work is and what social work does: in effect, the relevance of the specific (existential) context. This he says is important because it is this that helps to define the content of knowledge as well as its construction from the perspective of how underlying epistemic principles are utilised i.e. are they free of bias generated by the influence of overarching structural (situational) influences? (Witkin and Harrison 2001). Philp also points out that

... it is essential to see that if a form of knowledge exists which we can call 'social 
work knowledge' it does so because it is the product of a specific historical, social and economic situation and that it will be related, in the form it takes, to that situation. (Philp 1979: 87)

a point highly pertinent in today's contemporary professional world (Smith 2007). Within the social work literature, Drury-Hudson (1997) aims to

... provide a model of professional knowledge and argue that social workers should become more proficient in incorporating theoretical and empirical knowledge in their practice in order to improve accuracy and consistency in decision-making so as to provide a better standard of accountable practice. (p35)

In relation to this particular model she states that

It is considered that such a model is needed because often professional knowledge is discussed without any attempt being made to define what is meant by this term.(p37)

She then identifies from the literature 'Five principal knowledge forms... and together these form the basis of professional knowledge' (p37) defined as

the cumulated information or understanding derived from theory, research practice or experience considered to contribute to the profession's understanding of its work, and that serves as a guide to its practice. [(p.37)

These categories of knowledge are labelled theoretical, empirical, personal, practice and procedural and represent claims to different types of knowledge, each described in an attempt to differentiate their constituent elements and their interconnectedness.

More recently, this debate has evolved into a variegated discourse around (predominantly) the value of research-based knowledge versus knowledge from other sources via arguments for evidence-based practice (Gambrill 2013; Gilgun 2005; Sheldon and MacDonald 1999; Sackett, Rosenberg, Gray, Haynes and Richardson 1996; Sommerfeld 2005) through evidence-informed practice (Melnyk and Newhouse 2014), to a science of social work (Anastis 2014; Brekke 2012; Gehlert 2015; Göppner 2012; Longhofer and Floersch 2012; Marsh 2012; Sommerfeld 2014), with much less emphasis on production, use and transfer issues relating to other types of knowledge emanating from other sources and representing other ways of knowing - experiential, tacit, and common-sense (Brier 2000; Edwards and Daniels 2012; Kothari et al. 2012; Orlikowski 2006; Shaw 2014), and that of the role of context (Healy 2014; Gibbons 2000). However, that a more pluralistic and context-specific perspective is worthy of consideration is visible in the literature, although somewhat more mutedly (Avby, Nilsen and Ellström 2015; Ellis 2014; Gray, Joy, Plath and Webb 2012). 
However, Rutter and Fischer (2013) usefully note that

The application of knowledge is [therefore] highly contingent on context: and research knowledge competes with other, including powerful experiential, knowledge, as well as values, in guiding social care practice. (pp.6-7)

and that

... methodological quality cannot be the arbiter of what is evidence. The authority of research evidence over practitioner experience is also doubtful, yet there is relatively little discussion in the literature about power, authority and relevance to context. (p.9)

They suggest that it is the specific situational relevance at the level of individuals and their actions that should be the compass that guides the application of particular and specific forms of knowledge, not methodological or political dogma or the (economically-driven) demands of managerialism (Noordegraaf and Abma 2003) or other forms of political or professional ideology (Feldman and Johnston 2014).

There are though indications that the role of context, the substantive effects of fallibilism, and the reality of foundational constructs on knowledge production, use and dissemination are becoming more mainstream in certain areas of Scandinavia and northern Europe in what has been referred to as the 'practice turn' in social work research (Julkunen and Karvinen-Niinikoski 2014). There is an increasing recognition of the validity of a more action-oriented, pragmatically-focused approach to 'practice research' (Høgsbro 2015; Börjeson and Johansson 2014; Julkunen 2011; Rasmussen 2011; Saurama and Julkunen 2011; Paavola and Hakkarainen 2005) that has resonance with many principles derived from both Pragmatism and Critical Realism (Kjørstad 2008); Kivinen and Piiroinen 2004).

However, this apparent trend notwithstanding, within the UK and USA contexts, the literature remains consistent (if confused) in its (long-standing) recognition that the many elements of the current 'knowledge landscape' of social work (and arguably, many other human-service professions) are problematic (and not simply 'problematized'), and as a result, potentially divisive, and yet they continue to be argued over with little sign of functional agreement on how best to approach the issue of knowledge within professional practice (Gray, Joy, Plath and Webb 2012). The aspiration towards a more consensual approach is not simply an academic concern: social work as an activity (Ferguson 2011) is something that affects people's lives on a daily basis, so both how and what to use to inform those activities is a germane question, presupposing clarity regarding the purpose and function of the activity itself as well as the mechanisms that facilitate the construction of that which underpins it - knowledge (Fantl and McGrath 2009). In response to these issues, philosophical Pragmatism may have something to offer.

Pragmatism: An approach to integrating social work research and practice 
Any problem of scientific inquiry that does not grow out of actual (or 'practical') social conditions is factitious; it is arbitrarily set by the inquirer. (Dewey 1938: p499)

The task now is to articulate, contextualise and justify the introduction and use of an epistemological approach for social work (and related professions - see Schön 2001) that is able to provide a critical framework within which issues of knowledge definition, production, transfer, utilisation, dissemination and development can be readily located. The primary concern here has to be how to effectively include all relevant forms of knowledge and ways of knowing into the professional canon. The 'models' and approaches that are extant in the literature do not appear to articulate a coherent and plausible way forward to legitimise all forms of knowing in the search for 'what (really) works (most of the time)'. It is arguably the lack of engagement with the functional attributes of epistemology that represents one of the main barriers to effective knowledge production and use in professional practice.

How then are we to make the best use of epistemological principles within professional (social work) practice? One possibility is to adopt a pragmatic epistemology (Author's own 2016), the essence of which rests on a number of key features that provide both focus and a critical perspective. One of the strengths of Pragmatism is its capacity to collapse the distinction between epistemology and ontology, such that the '...embodied, enacted character of cognition lies at the centre of a constructivist, practical, and non-dualistic view of the world.' (Pratt 2016: 2). It avoids a reductionist view of ontology by refusing to (simplistically) categorize it as a function of epistemology - the view that our ontology is defined only by reference to what we know about the world - our epistemology. It therefore explicitly acknowledges that there is an external reality, independent of the mind, whilst recognising that both perceptual and cognitive functions have a role in shaping this external reality, as does action (Joas 1996). It thus provides a basis for the active consideration of both the ontological and epistemological nature of existence - the interplay of the a priori (Bhaskar 1975) and the socially mediated (Searle 1998, 2006; Berger and Luckmann 1966: Hacking 2000). Pragmatism also aligns to instrumentalism in terms of having a focus on addressing 'real-world' problems, foregrounding the importance of experience as the cornerstone of inquiry (Martela 2015; Koons 2009; Shook and Margolis 2009; Cooke 2006). It therefore offers a distinctive view regarding the nature of ontology, the structure and role of epistemology and the nature of scientific inquiry, particularly in the form of Pragmatism articulated by John Dewey in Logic: The Theory of Inquiry (1938), although the framework also draws on the thinking and writings of Charles Sanders Peirce (1905), William James (1977, 1909), G.H Mead (1967) and C.H Cooley (1902, 1956).

The origins of pragmatism are usually attributed to the works of Peirce (1877), James (1977; 1968) and Dewey (1929/1980, 1929a, 1938), although earlier manifestations of some its central tenets can be identified in the works of the Scottish 
Enlightenment philosophers Thomas Reid (1764/2000) (Magnus 2004; Fieser 2000) and David Hume. More specifically to social work, the ideas and practices of Jane Addams, Mary Richmond, the Settlement Movement and the Charitable Organisation Society in the USA, and Thomas Chalmers in Glasgow some years before (McCaffrey 1981) and their efforts to create what Franklin (1986) refers to as a 'paradigm shift... in social work' [that] 'interactively shaped the social purposes of the social work profession... from one of moral certainty to one of rational inquiry...' (p505) are also significant (see also Soydan 1999; Rosiek and Pratt 2013).

These thinkers argued that insofar as the acceptance of any proposed belief is concerned, its acceptability, and therefore its use, is ultimately a function of its utility in terms of its capacity to promote our adaption under the principle of homeostasis. Put differently, we will be rationally justified in accepting a proposition $(P)$ about the world as being true if, on the basis of reasonable and reasoned inquiry we have no current and alternate reason to think otherwise about it, such that the acceptance of $P$ at this time will provide better results or outcomes than if we did not accept $P$ (Peirce 1907; Almeder 2007 - italics mine). Importantly, these propositions may be derived from any source and may be 'merely' presumptive. For example, no one has ever seen gravity, and yet physicists (and the rest of us) accept that it exists because to do so enables us to explain and make sense of many things in the world. Physics then, for many the most fundamental of all the sciences, is seen to operate on the basis of a significant presumption that is rationally accepted, simply because not to do so would be unthinkable. Almeder (2007) notes:

So characterized, sophisticated natural scientists can be, and have been, pragmatists simply for believing that the fruits of standard scientific methodology generally tend to produce beliefs better by way of providing suitable predictions for biological success than any other available method. (pp171-2)

In relation to everyday life, pragmatists would contend that there are in fact some proposed beliefs that we can neither establish nor refute by reference to either inductive or deductive methods as derived from natural or social scientific methodologies. These are nonetheless epistemologically sound because when adopted as true, they make things 'work' and help us to make sense of the world. What this means is that if the adoption of a presumptively held belief derived from practice experience, intuition or any other source makes things 'work', then it has as much validity as adopted beliefs derived from other, more 'formal' and/or 'scientific' sources. If the purpose of the adoption of a particular belief is to produce consequences that enhance adaptation, functioning or well being, broadly conceived in-line with the Aristotelian concept of eudemonia (Bogolub 2010; Bloor 2010; Jordan 2008; Knight 2007), it is justified under the pragmatic principle (Koons 2009). A pragmatic epistemology is essentially a reconstruction of the classic account of the theory of knowledge that takes account of human limitations from a cognitive perspective (by addressing the problem of infinite regress for example) as well as the need for us to 
know things that help us to function in the everyday world (Talisse and Aikin 2008). Brandom (2001) refers to this as a 'rationalist pragmatism' (p11) and when derived from and applied back to social work, this praxis-based knowledge (Petersén and Olsson 2014) is not only epistemologically, but morally more credible if we think back to the very purposes of social work (Elkjaer $\&$ Buch, 2015).

The framework suggested here is a framework for 'scientific' inquiry - a pragmatic theory of 'scientific' inquiry. The use of inverted commas is simply to re-emphasise that the nature of 'scientific' is a contested notion and that the pragmatic emphasis is more on the word inquiry. Dewey himself was clear on this point:

Sciences themselves are outgrowths of some phase of social culture, from which they derive their instruments, physical and intellectual, and by which their problems and aims are set. (Dewey 1938: 311)

The framework is built upon and around the pragmatic principle, the basis of which is:

A Person will be rationally justified in accepting a proposed proposition $[P]$ as true if: i): there is at that time no currently available conscious inference, inductive or deductive, from any other previously known or justified beliefs that would either confirm or disconfirm $P$; and:

ii): there is a distinct possibility that by accepting $P$ as being true or likely to be so, it will produce consequences more likely to contribute to the enhancement of cognitive and/or moral utility than would be the case if we did not accept $P$ as being true, or likely to be so.

At the most basic level, as human beings we need to act in relation to the external world. Merely observing the world is not sufficient; we engage in and with the world and as such, all the beliefs (knowledge) we have are essentially (revisable) guides to future action based on the outcomes of our experiences. In this way, pragmatism locates the value of knowledge (beliefs) in the nature of our practical existence and experience. The aim of pragmatism and its approach is to utilise our experience as a means by which we build knowledge of the world in the shape of 'warranted assertions' (Dewey 1938: 7), rather than absolute knowledge or belief, based on the appreciation that we can never have a complete understanding of anything (c/f Hume 1748/2008; Lange 2008).

Any 'warranted assertion' is judged in terms of its capacity to enhance the achievement of our goals, whatever they might be: conceptual understanding, improved practical action or being able just to 'do' (social) life a little better than before. This approach provides each of us with the opportunity to generate our own forms of 'knowing' and 'doing' grounded in our own reality, and that helps us to make sense of the world. As each of us will have our own preferences regarding the 
'warranted assertions' or beliefs about the world that work best for us, we can avoid the descent into absolute relativism and scepticism (Grayling 2009) as our nature is such as to lead us to prefer and to repeat those actions ('habits' underpinned by our beliefs) that are more likely to lead to the achievement of our goals, at whatever level these may be at, including those assertions that act at the collective level. As Hogan (2009) notes, ‘...our rules of method and our ontology emerge out of our struggle to adjust to the problems of living.' (p386), resonating with Bourdieu's notions of 'field' and 'habitus'. This of course should not be taken to imply that we can believe anything we want to: this would run counter to the pragmatic maxim as well as to what Wittgenstein referred to as 'background beliefs' (Wittgenstein 1969: para 162). We all rely upon certain standards regarding what is plausible in terms of what to believe, and usefully this minimises (though does not eradicate absolutely) the possibility of anarchic relativism.

Taking the above into consideration, we can now consider what a Pragmatic approach might look like. In essence, there are three elements to consider in relation to the process of inquiry. Firstly, when we experience a situation we are unfamiliar with, or one in which we experience some form of level of doubt, we recognise the need to respond to this by adjusting our behaviour and responses in some way. At a basic level, this may involve pure reflexes - a biological and pre-cognitive response, or it may involve intuition or the utilisation of past experiences in the form of habits. Such a response may be appropriate because it is successful and therefore functional - it fulfils the second element of the pragmatic principle. However, if the response requires a more cognitive and reflective approach, we then engage in a different form of inquiry, that which '... is the controlled or directed transformation of an indeterminate situation into one that is so determinate in its constituent distinctions and relations as to convert the elements of the original situation into a unified whole.' (Dewey 1938 pp104-105). This type of approach is not just relevant to what we might refer to as 'scientific' inquiry. Note that Dewey's rendition of an inquiry does not tie itself down to any particular approach or method. The purpose of inquiry is to resolve or alter the situation: the means by which this takes place are to be determined by reference to the nature of the situation, the context and the means available to the individual, the most basic of which is the capacity to reflect on the situation, such that one becomes aware of the need to act (Dewey 1929a).

Thus, inquiry using 'scientific' methods or 'common-sense' (with its parallels to pragmatism - see Jackson 2014; Lundestad 2008) instigates a process of reflection, exploration and iteration - abduction (Tavory and Timmermans 2014), a 'scientific attitude'. 'The scientific attitude may also be defined as that which is capable of enjoying the doubtful; scientific method is, in one aspect, a technique for making use of doubt by converting it into operations of infinite inquiry.' (Dewey 1929 p228). The inquiry thus engages principles of reflection and systematic iteration, moving between our current situation and how we understand it, our past experiences that may have some similarities to our current one and all the 'data' we have in front of us. This does not 
mean that we have to adopt formal, scientific procedures. Dewey (1938) reminds us: 'Scientific subject-matter and procedures grow out of the direct problems and methods of common sense, of practical uses and enjoyments.' (p66). The aim of inquiry, simply, is to unify all that we have before us into a coherent whole such that we reach a 'warranted assertion' - an understanding or solution that works - then - and which can then form the basis of future actions. The warranted assertion is a hypothesis regarding whether or not we have achieved our aim - the resolution of indeterminacy. If we feel we have, then the particular inquiry ceases; if we feel we have not resolved matters satisfactorily by reference to our existential and experiential situation, we continue to inquire until we do reach some form of conclusion, one that is, of necessity, provisional, as all conclusions are (Toulmin 1958).

In relation to the more collective aspects of inquiry, and that which relates to the sorts of inquiry undertaken in the context of social work practice and research (and other professions), we should note that the main difference (and the only one from a pragmatist perspective) is that we have to demonstrate an adherence to the generally accepted standards of the field or profession - of the 'community of inquiry (Calvert-Minor 2011; Schatzki 1996). This is an important point because it addresses the assumption that there is a legitimate hierarchy of inquiry, classically represented by the view that a Random Controlled Trial is a 'better' type of inquiry than interviews or observations for example. In pragmatism, and in social life generally, the final arbiter of the effectiveness of any inquiry is whether it achieves its purposes. Powell (2001) articulates this well, asserting that: 'To a pragmatist, the mandate of science is not to find truth or reality, the existence of which is perpetually in dispute, but to facilitate human problem-solving' (p884). This however does not equate with 'the ends justifying the means', or being unaware of the power underlying the doxa - '...that which goes without saying, because it comes without saying' (Bourdieu 1972: 169; Eagleton and Bourdieu 1992). The value-base of social work, reflexivity, professional and research standards and professional ethics all serve to provide a backstop to maintain the integrity of Pragmatic processes of inquiry.

Any theoretical model is nothing more than an organising framework through which problems are perceived and subsequently organised. In order to understand the role such a Pragmatist model has, we can refer to Dewey's notion of a general 'theory of inquiry' (Dewey 1938), most clearly articulated in How We Think (1910/2007). Here, he outlines a five-stage process:

i): a felt difficulty;

ii): its location and definition [problem identification];

iii): suggestion of possible solutions [theory application];

iv): development by reasoning of the bearings of the suggestion [inquiry];

v): further observation and experiment leading to its acceptance or rejection, that is, the conclusion of belief or disbelief [reflection; phronesis; philosophising] (p 72). 
Any theoretical model must be consciously explicated and subjected to continued evaluation and re-evaluation. A model too is but a tool - much like complex statistical factor analysis for example - as complex as they are, they are a means to an end, as is Dewey's (or anyone else's) model. However, of significance here is Dewey's insistence on a general theory of inquiry rather than a theory (or model) of scientific inquiry. The focus is on the inquiry; and a pragmatic model permits common-sense inquiry as well as scientific inquiry. In this way, Pragmatism offers us all a way out of 'idealised' notions of science. The issue is not methodological, but one of process and progress towards one's goals which, under the pragmatic maxim, are (simply) to maximise functioning and stability within the context of everyday human life (Prus and Puddephatt 2009). Rorty (1991) is a staunch critic of the scientific method - for him, there is no method or approach per se that can reliably give the truth. Instead, different truth propositions have either better or worse pragmatic consequences. In this, Rorty not only eschews the 'tyranny of method' (Bernstein 2010), but also avoids the 'trap' of relativism because he holds on to the analysis of consequences and sees these as the arbiter of the effectiveness of the Pragmatic approach to inquiry.

One of the critical aspects of the Pragmatic model is its emphasis on critiquing all outcomes to see if they can be improved upon. With its acceptance of fallibilism as a core construct, Pragmatism permits of new possibilities at any and every stage. It therefore provides an inherently critical perspective on knowledge - in terms of its production, use, translation, development and dissemination, and therefore represents a 'healing philosophy' - an integrative approach for (emergent) postpositivist thinking and methodologies. Pragmatism thus offers us a way out of 'idealised' notions of science and instead provides a platform upon which inquiry, in all its manifestations, can rest much more easily.

The justification for the Pragmatic model is that it provides for the possibility of better consequences for social work and other professions simply because it enables a plurality of views (methods) to be a part of its overall schema. Pragmatism also offers us a view of nature (the ontological world) that is essentially systemic, which is coherent with the underpinning, holistic ethos of professional social work and other human service professions. Pragmatic metaphysics are important in terms of how its overall orientation enables us to locate the individual within context. Pragmatism takes account of all levels of existence - physico-chemical (the physical world), psycho-physical (biological) and that of 'mind' (psychological) (Dewey 1929a) in much the same way as those contemporary ecological models referred to above do, even though the levels may have different labels. Nonetheless, these help emphasise the intermingling of psychological and, importantly, cultural beliefs and perceptions, all of which inform knowledge production and use, based on the integration of ontology and epistemology (Milton 2006; Kivinen and Piiroinen 2004). 


\section{Pragmatism and social work practice}

The practice of professional social work has changed significantly since its appearance in the late $19^{\text {th }}$ century (Bamford 2015; Pierson 2011), and in its evolution we have seen too often the effects of poor practice and of sometimes failing to act on the basis of what we think we know (Laming 2003; 2009). Sometimes action has to be taken on the basis of 'inference to the best explanation' (Lipton 2004; Goldstein 2011) simply because that is all there is. And in the real world of real people and real social work, trying to deal with real difficulties in real time (Ferguson 2011), we often have to act on the basis of the best we think we know, and sometimes that means 'in the moment'. Acting thus is either praiseworthy and seen as the exercise of true expertise when it goes well, or as foolhardy and acting on the basis of personal preferences and a lack of objective knowledge when it goes wrong. We cannot have it both ways and it seems that the currently preferred approach to knowledge creation may well be influenced by powerful interests and their particular epistemic cultures and ideologies, described by Knorr-Cetina (1991) as the

... amalgam of arrangements and mechanisms - bonded through affinity, necessity and historical coincidence - which in a given field, make up how we know what we know. (p1)

and that these effectively determine what is actually allowed to be seen as 'professional knowledge'.

As referred to earlier, Foucault's notion of 'regimes of truth' has contemporary resonance through the articulation of governmental policy regarding knowledge creation and use such that the transfer of research-based knowledge to practice continues to be a source of concern (Alley, Jackson and Shakya 2015; Plath 2014; Armstrong et al 2013; Gray, Joy, Plath and Webb 2012), as does how it is then used (Luitgarden 2009) and understood (Nevo and Slonim-Nevo 2011). In addition, less emphasis is still placed upon context-relevant knowledge and the value of using professional discretion and judgement (Høybye-Mortensen 2015; Shotter and Tsoukas 2014a, 2014b; Gambrill 2011) to help navigate knowledge use than on the 'application' of evidence-based findings. These matters could be addressed by reference to a more integrative approach, as social work like any profession has to be accountable for its actions, but to assume that such accountability will be enhanced by reference to the use of particular forms of knowledge to the diminution of other forms is a dangerous practice. We have to be more accepting of a plurality of approaches to knowledge creation and use in order to maximise social works' potential in all areas (Munro 2011), even though this perhaps challenges the interests and claims inherent within neo-liberalism and its practices in the form of new public management (Hughes and Wearing 2016; Jordan and Drakeford 2012; Jordan and Jordan 2000), leading in some instances to striking differences in approaches 
to knowledge management depending on the degree of power of one particular discourse over another (Hübner 2016).

\section{Conclusion}

In this paper, I have suggested that one of the central functions of philosophy is to provide us with general principles by which we can conduct our affairs, and in social work we have already adopted one branch of philosophy quite readily, that of ethics or moral philosophy. I argue that by referring to another branch of philosophy, epistemology, and more specifically to Pragmatism, we can more confidently inform our professional practice and enhance its credibility and impact. That a Pragmatic epistemology can tolerate a multiplicity of paradigmatic approaches (Kuhn 1970) and integrate them into a functional whole, avoiding the creation of 'knowledge hierarchies' (Goldenberg 2009), is clearly apparent. Understanding how knowledge 'happens' by reference to the real world and ontology (Bunge 1977; 1979), what shape it can take, why and how it is always and necessarily provisional and context-based, and how it can grow and change can help practitioners feel more comfortable in using, creatively, intelligently and empathically the rich variety of knowledge forms they possess and come into contact with on a daily basis (Howe 2008, 2012).

Lorenz (2016) comments upon how social work's efforts to develop a research base has resulted in tensions because of the demands for both positivistic models and those located more clearly within the hermeneutic tradition. This tension he argues, should not be seen negatively, but rather as an 'impulse to acknowledge specific human qualities' ( $\mathrm{p} 455$ ), providing opportunities to better understand the future direction of epistemology. He goes on to argue that this situation provides an opportunity to highlight how social work has the

... capacity to confront uncertainty, to incorporate doubts constructively, to relate research ultimately always to the question of 'what matters', practically and ethically, and what matters is nothing less than understanding and enhancing the human condition' (p455)

and contribute not only to social work research, but the whole enterprise of research more generally because of these (ubiquitous) strengths.

It is in such a nexus that Pragmatism can be seen as a means of integrating methodologies and theoretical approaches to facilitate making the best use of all the knowledge and methods available to us - at least in principal. We can 'open the box', and whether this be 'objective' data or 'subjective' meanings, Pragmatism reminds us that the issue is to utilise all of that which enhances well-being through engagement and action (Thayer 1980), including policy formulations 
operating at the structural level and impacting upon the metaphysical and therefore, conceptions of well-being (Orme and Briar-Lawson 2010; Jordan 2008). Pragmatism is therefore not hierarchical in its utilisation of approaches to achieve its stated aims - the enhancement of the human condition. It therefore succeeds in being able to raise questions as to the validity of certain types of approaches to knowledge production and utilisation by reference to whether these produce better outcomes - it has the potential to 'trouble' many of our assumptions regarding professional practices, particularly as articulating the political and cost-efficiency aspects of practice is often difficult for many practitioners (Reisch and Jani 2012). Additionally, the (omni-) presence of neoliberal ideology, with its tendency to focus on individual accountability to the exclusion of the role of broader, social factors in the identification and resolution of difficulties, similarly serves to marginalise the politically oriented aspects of social work activity (Lorenz 2016; Howe 2014). Pragmatism could act as a useful counter to this tendency.

Thus, with the opportunity to utilise a Pragmatic framework to draw upon knowledge from a range of sources, and respond effectively to real-life difficulties, bringing about meaningful change in people's lives because what a social worker did actually worked and made a difference, Pragmatism provides a clear criterion upon which to base evaluations of effectiveness (Julkunen 2011). Pragmatism, as both a social theory, and as an epistemological approach affords the profession the opportunity to utilise all of its strengths by embracing plurality and diversity in terms of both a 'world-view' and an inclusive approach to research and practice. Pragmatism offers huge potentials and is worthy of further discussion and application.

\section{References}

Author's Own (2010)

Author's Own (2011)

Author's Own (2014)

Author's Own (2016)

Alexanderson, K., Beijer, E., Bengtsson, S., Hyvönen, U., Karlsson, P and Nyman, M (2009): 'Producing and Consuming Knowledge in Social Work Practice: Research and Development Activities in a Swedish Context', Evidence and Policy, 5(2), 127-139.

Alley, S., Jackson, S.F and Shakya, Y.B (2015): 'Reflexivity: A Methodological Tool in the Knowledge translation Process?', Health Promotion Practice DOI: 10.1177/1524839914568344.

Almeder, R (2007): 'Pragmatism and the Philosophy of Science: A Critical Survey', International Studies in the Philosophy of Science, 21(2), 171-95.

Anastis, J.W (2014): 'The Science of Social Work and Its Relationship to Social Work Practice'. Research on Social Work Practice 24, 571-580.

Armstrong, R., Waters, E., Dobbins, M., Anderson, L., Moore, L., Petticrew, M., Clark, R., Pettman, T.L., Burns, C., Moodie, M., Conning, R and Swinburn, B (2013): 'Knowledge Translation Strategies to Improve the Use of Evidence in Public Health Decision Making in Local Government: Intervention, 
Design and Implementation Plan', Implementation Science, 8, 121.

Audi, R (2011): Epistemology: A Contemporary Introduction to the Theory of Knowledge ( $3^{\text {rd }}$ Ed). London, UK. Routledge.

Avby, G., Nilsen, P and Dahlgren, M.A (2014): 'Ways of Understanding Evidence-Based Practice: A Qualitative Study', British Journal of Social Work, 44, 1366-1383.

Avby, G., Nilsen, P., and Ellström, P. E. (2015): Knowledge Use and Learning in Everyday Social Work Practice: A Study in Child Investigation Work, Child \& Family Social Work. DOI: 10.1111/cfs.12227. Ayer, A.J (1963): The Problem of Knowledge. London, UK. Macmillan.

Baars, T (2010): 'Experiential Science: Towards an Integration of Implicit and reflected PractitionerExpert Knowledge in the Scientific Development of Organic Farming', Journal of Agricultural and Environmental Ethics, DOI 10.1007/s10806-010-9281-3

Bailey, D (2014): 'Reflections on the Opportunities and Challenges for Practice research in Social Work', Social Work and Social Sciences Review, 15(2), 3-6.

Bamford, T (2015): A Contemporary History of Social Work: Learning from the Past. Bristol, UK. Policy Press. Banks, S (2014): Ethics. Bristol, UK. Policy Press.

Bayes, $\mathrm{T}$ and Price, R (1763): 'An essay towards solving a problem in the Doctrine of Chance. By the late Rev. Mr Bayes, communicated by Mr Price in a letter to John Canton, AMFRS' in Philosophical Transactions of the Royal Society of London 53 (0) pp 370-418.

Berger, P and Luckmann, T (1966): The social construction of reality. London, UK. Peregrine Press/ Penquin.

Bernard-Donals, M (1998): The Practice of Theory: Rhetoric, Knowledge and Pedagogy in the Academy. Cambridge, UK. Cambridge University Press.

Bernstein, R.J (2010): The Pragmatic Turn. Cambridge. The Polity Press.

Bhaskar, R (1975/2008): A Realist Theory of Science. London, UK. Verso Books.

Bhaskar, R (1979): The Possibility of Naturalism: A Philosophical Critique of the Contemporary Human Sciences. Sussex, UK. The Harvester Press.

Blackburn, S (2006): Truth: A Guide for the Perplexed. Harmondsworth, UK. Penguin Books.

Bloor, M (2010): 'The Researcher's Obligation to Bring About Good', Qualitative Social Work, 9(1), 17-20.

Blumer, H (1969): Symbolic Interactionism: Perspective and Method. Englewood Cliffs, N.J, USA. PrenticeHall.

Bogolub, E (2010): 'The Obligation to Bring About Good in Social Work Research', Qualitative Social Work, 9(1), 9-15.

Börjeson, M and Johansson, K (2014): 'In Search for a Model for Knowledge Production and Practice research in Swedish Social Work', Nordic Social Work research, 4, Suppl, 70-85.

Bourdieu, P (1977): Outline of a Theory of Practice. Cambridge, UK. Cambridge University Press.

Brandom, R (2001): Articulating Reasons. Cambridge, MA, USA. Harvard University Press.

Brekke, J.S (2012): Shaping a Science of Social Work. Research on Social Work Practice 22, 455-464.

Brier, S (2000): Trans-Scientific Frameworks of Knowing: Complementarity Views of the Different Types of Human Knowledge. Systems Research and Behavioural Science 17, 433-458.

Briggs, H. E., Caroline, S., \& Briggs, A. C. (2016). The contributions of applied behavior analysis and behavior theory to innovative research and practice cultures in social work. Journal of EvidenceInformed Social Work. doi:10.1080/23761407.2015. 1086710

Broad, C.D (1952): Ethics and the History of Philosophy. London, UK. Routledge and Kegan Paul.

Bronfenbrenner, U (1979): The Ecology of Human Development. Cambridge, MA, USA. Harvard.

Brown, J. (2015): 'Contextualism about Evidential Support', Philosophy and Phenomenological Research, doi:10.1111/phpr.12164.

Bunge, M (1977): Treatise on Basic Philosophy: Volume 3-Ontology I: The Furniture of the World. Dordrecht, Germany. Reidl. Ontology $1 \& 2$ here (in Milton)

Bunge, M (1979): Treatise on Basic Philosophy: Volume 4 - Ontology II: A World of Systems. Dordrecht, 
Germany. Reidl.

Calvert-Minor, C (2011): "Epistemological Communities' and the Problem of Epistemic Agency', Social Epistemology, 25(4), 341-360.

Carew, R (1979): 'The Place of Knowledge in Social Work Activity', British Journal of Social Work, 9 , 349-364.

Church, I.M., 2013: 'Manifest Failure Failure: The Gettier Problem Revived', Philosophia, 41(1), 171-177.

Comesaña, J (2008): 'Epistemic Pragmatism: An Argument Against Moderation', Midwest Epistemology Forum, Lincoln, USA. University of Nebraska.

Cooke, E (2006): Peirce's Pragmatic Theory of Inquiry: Fallibilism and Indeterminacy. London, UK. Continuum Publishing.

Cooley, C. H. (1902): Human Nature and the Social Order. New York, USA. Scribner.

Cooley, C.H (1956): Social Organization. Chicago, USA. Transaction Publishers.

Curnock, K and Hardiker, P (1979): Towards Practice Theory: Skills and Methods in Social Assessments. London, UK. Routledge and Kegan Paul.

Devaney, J., Lazenbatt. A and Bunting, L (2011): 'Inquiring into Non-Accidental Child Deaths: Reviewing the Review Process', British Journal of Social Work, 41, 242-60.

Dewey, J (1910/2007). How We Think. Boston. D.C., USA. Heath \& Co.

Dewey, J (1922/2002): Human Nature and Conduct. New York, USA. Dover Books.

Dewey, J (1929/1980): The Quest for Certainty. New York, USA. Perigee Books.

Dewey, J (1929a): Experience and Nature (2 $\left.{ }^{\text {nd }} e d\right)$. LaSalle IL, USA. Open Court Publishing.

Dewey, J (1938): Logic: The Theory of Inquiry. New York, USA. Henry Holt.

Dreyfus, H.L and Dreyfus, S.E (1986): Mind Over Machine: The Power of Human Intuition and Expertise in the Era of the Computer. Oxford, UK. Blackwell.

Drury-Hudson, J (1997): 'A Model of professional Knowledge for Social Work Practice', Australian Social Work, 50(3), 35-44.

Duhem, P (1954): The Aim and Structure of Physical Theory. Princeton, USA. Princeton University Press.

Eagleton, T., \& Bourdieu, P. (1992): 'Doxa and Common Life', New Left Review, (191), 111.

Edwards, A and Daniels, H (2012): The Knowledge that Matters in Professional Practices. Journal of Education and Work 25(1), 39-58.

Elkjaer, B., \& Buch, A. (2015): Pragmatism and Practice Theory: Convergences or collisions. Conference Paper presented at OLKC, Malan, Italy. Aarhus University, Denmark.

Ellis, K (2014): Professional Discretion and Adult Social Work: Exploring Its Nature and Scope on the Front Line of Personalisation. British Journal of Social Work 44, 2272-2289.

Epstein, B (2016): 'A Framework for Social Ontology', Philosophy of the Social Sciences, 46(2), 147-167.

Epstein, I., Fisher, M., Julkunen, I., Uggerhoj, L., Austin, M. J., \& Sim, T. (2015). The New York statement on the evolving definition of practice research designed for continuing dialogue: A bulletin from the 3rd International Conference on Practice Research (2014). Research on Social Work Practice, 25, 711-714

Eraut, M (1994): Developing Professional Knowledge and Competence. London, UK. Routledge Falmer.

Etzioni, A (1969): The semi-professions and their organization: Teachers, nurses, social workers. New York, USA. Free Press.

Evans, T and Hardy, M (with Shaw, I) (2010): Evidence and Knowledge for Practice. Bristol, UK. Polity Press. Fantl, J and McGrath, M (2009): Knowledge in an Uncertain World. Oxford, UK. Oxford University Press. Feldman, S., \&Johnston, C. (2014). Understanding the determinants of political ideology: Implications of structural complexity. Political Psychology, 35, 337-358.

Ferguson, H (2011): Child Protection Practice. Basingstoke, UK. Palgrave Macmillan.

Fieser, J (Ed) (2000): A Bibliography of Scottish Common-Sense Philosophy. Bristol, UK. Thoemmes Press.

Fish, S (1989): Doing What Comes Naturally: Change, Rhetoric, and the Practice of Theory in Literary and Legal Studies. Oxford, UK. Clarendon Press. 
Flexner, A (1915/2001): 'Is Social Work a Profession?, Research on Social Work Practice, 11(2), 152-65. [Also in Studies in Social Work, 4, 2-24.

Flyvbjerg, B (2001): Making Social Science Matter: Why Social Inquiry Fails and How it Can Succeed Again. Cambridge, UK. Cambridge University Press.

Flyvbjerg, B., Landman, T and Schram, S (Eds) (2012): Real Social Science: Applied Phronesis. New York, USA. Cambridge University Press.

Fook, J., Ryan, M and Hawkins, L (2000): Professional Expertise: Practice, Theory and education for Working in Uncertainty. London, UK. Whiting and Birch

Fook, J., D’Avray, L., Norrie, C., Psoinos, M., Lamb, B and Ross, F (2013): 'Taking the Long View: Exploring the Development of Interprofessional Education', Journal of Interprofessional Care, 27(4), 286-291.

Foucault, M (1974): The Archaeology of Knowledge. London, UK. Tavistock.

Franklin, D.L (1986): 'Mary Richmond and Jane Addams: From Moral Certainty to Rational Inquiry in Social Work', Social Service Review, 60(4), 504-525.

Gambrill, E (2011): 'Evidence-Based Practice and the Ethics of Discretion', Journal of Social Work, 11, $26-48$.

Gambrill, E (2013): Social Work Practice: A Critical Thinker's Guide (3 ${ }^{\text {rd }}$ Ed). Oxford, UK. Oxford University Press.

Gant, V (2016): 'Reflections on a birthday: ....QQualitative Social Work.

Garrett, P.M., (2015a) 'Introducing Michael Gove to Loïc Wacquant': Why Social Work Needs Critical Sociology. British Journal of Social Work, p.bcv024.

Garrett, P.M., 2013. Social Work and Social Theory: Making Connections. Bristol, UK. Policy Press.

Garrett, P.M., 2011. From 'Solid Modernity' to 'Liquid Modernity'? Zygmunt Bauman and Social Work. British Journal of Social Work, p.bcr094.

Garrett, P.M., 2009. Marx and Modernization: Reading Capital as Social Critique and Inspiration for Social Work Resistance to Neoliberalization. Journal of Social Work, 9(2), 199-221.

Garrett, P.M., 2007a. The Relevance of Bourdieu for Social Work A Reflection on Obstacles and Omissions. Journal of Social Work, 7(3), 355-379.

Garrett, P.M., 2007b. Making social work more Bourdieusian: Why the social professions should critically engage with the work of Pierre Bourdieu. European Journal of Social Work, 10(2), 225-243.

Gehlert, S (2015): Social Work and Science. Research on Social Work Practice DOI: 10.1177/1049731515570138.

Gettier, EL (1963): 'Is Justified True Belief Knowledge?' Analysis, 23(6), 121-23.

Gibbons, M., Limoges, C., Nowotny, H., Schwartzman, S., Scott, P and Trow, M (1994): The New Production of Knowledge: The Dynamics of Science and Research in Contemporary Societies. London, UK. Sage.

Gibbons, M (2000): 'Context-Sensitive Science: Mode 2 Society and the Emergence of Context-Sensitive Science', Science and Public Policy, 27(3), 159-163.

Gilgun, JF and Adams, LS (2002): 'The Nature and Usefulness of Qualitative Social Work Research: Some Thoughts and an Invitation to Dialogue', Qualitative Social Work, 1, 39-55.

Gilgun, J. F. (2005). The four cornerstones of evidence-based practice in social work. Research on Social Work Practice, 15(1), 52-61.

Gitterman, A., and Germain, C. B. (2013): The Life Model of Social Work Practice: Advances in Theory and Practice. Columbia, USA. Columbia University Press.

Goldenberg, M.J (2009): 'Iconoclast or Creed? Objectivism, Pragmatism and the Hierarchy of Evidence', Perspectives in Biology and Medicine, 52(2), 168-87.

Goldstein, RN (2011): Inference to the best explanation [online] New York. Edge World Question Centre. Edge Foundation Inc. Available from http://www.edge.org/q2011/q11_3.html\#goldstein

Göppner, H.J (2012): Epistemological Issues of Social Work Science as a Translational Action Science. 
Research on Social Work Practice 22, 542-547.

Göppner, HJ and Hämäläinen, J (2007): 'Developing a Science of Social Work', Journal of Social Work, 7,269-87.

Grace, C. and Wilkinson, P (1978): Negotiating the Law: Social Work and Legal

Services. London, UK. Routledge and Kegan Paul.

Gray, M., Joy, E., Plath, D., \&Webb, S. A. (2012): What Supports and Impedes Evidence-Based Practice Implementation? A Survey of Australian Social Workers. British Journal of Social Work DOI: 10.1093/ bjsw/bct123.

Gray, M and Schubert, L (2012): 'Sustainable Social Work: Modelling Knowledge Production, transfer and Evidence-Based practice', International Journal of Social Welfare 21, 203-214.

Gray, M and Schubert, L (2013): 'Knowing what we know about knowledge in social work: The search for a comprehensive model of knowledge production', International Journal of Social Welfare, 22, 334-346.

Gray, M and Webb, S (2013): The New Politics of Social Work. Basingstoke, UK. Palgrave Macmillan.

Grayling, A (2009): Scepticism and the Possibility of Knowledge. London, UK. Continuum.

Gredig, D and Sommerfeld, P (2008): 'New Proposals for Generating and Exploiting Solution-Oriented Knowledge', Research on Social Work Practice, 18(4), 292-300.

Greenhalgh, T et al (2016): 'An Open Letter to the BMJ Editors on Qualitative Research' BMJ 352: i563/ i957.

Grimwood, T (2016): Key Debates in Social Work and Philosophy. Abingdon, UK. Routledge.

Hacking, I (2000): The Social Construction of What? Harvard, USA. Harvard University Press.

Haig, B.D (2008): 'Précis of 'An Abductive Theory of Scientific Method", Journal of Clinical Psychology, 64(9), 1019-1022.

Hannon, M., 2014. Fallibilism and the Value of knowledge, Synthese, 191(6), 1119-1146.

Harth, M. (2014) 'Is Relative Truth Really Truth? Dialectica, 68, 409-428.

Harrikari, T., Rauhaka, P-L and Virokannas, E (Eds) (2014): Social Change and Social Work: The Changing Societal Conditions of Social Work in Time and Place. Abingdon, UK. Routledge.

Healy, K. (2014). Social Work Theories in Context: Creating Frameworks for Practice ( $2^{\text {nd }}$ Ed). Basingstoke, UK. Palgrave Macmillan.

Heinsch, M., Gray, M., and Sharland, E. (2015): 'Re-conceptualising the Link Between Research and Practice in Social Work: A Literature Review on Knowledge Utilisation', International Journal of Social Welfare DOI: 10.1111/ijsw.12164.

Hempel, C.G (1966): Philosophy of Natural Science. Englewood Cliffs, NJ, USA. Prentice-Hall.

Herring, J (2016): Vulnerable Adults and the Law. Oxford, UK. Oxford University Press.

Hogan, B (2009): 'Towards a Truly Pragmatic Philosophy of Social Science', Human Studies, 32, 383-389.

Høgsbro, K (2015): 'Evidence and Research Designs in Applied Sociology and Social Work Research', Nordic Social Work Research, 5, Supp1, 56-70.

Hood, R (2012): 'A Critical Realist Model of Complexity for Interprofessional Working', Journal of Interprofessional Care, 26(1), 6-12.

Houston, S (2010): 'Prising Open the Black Box: Critical Realism, Action research and Social Work', Qualitative Social Work, 9(1), 73-91.

Howe, D (1980): 'Inflated States and Empty Theories in Social Work', British Journal of Social Work, 10, $317-40$.

Howe, D. (2008): The Emotionally Intelligent Social Worker. Basingstoke, UK. Palgrave Macmillan.

Howe, D. (2012): Empathy: What it is and Why It Matters. Basingstoke, UK. Palgrave Macmillan.

Howe, D (2014): The Compleat Social Worker. Basingstoke, UK. Palgrave Macmillan.

Howson, C (2000): Hume's Problem: Induction and the Justification of Belief. Oxford, UK. Oxford University Press.

Høybye-Mortensen, M (2015): 'Decision-Making Tools and Their Influence on caseworkers' Room for Discretion', British Journal of Social Work, 45(2), 600-615. 
Hübner, L (2016): 'Reflections on Knowledge Management and Evidence-Based Practice in the Personal Social Services of Finland and Sweden', Nordic Social Work Research, 6(2), 114-125.

Hughes, M and Wearing, M (2016): Organisations and Management in Social Work: Everyday Action for Change. London, UK. Sage.

Hugman, R (2013): Culture, Values and Ethics in Social Work: Embracing Diversity. Abingdon, UK. Routledge.

Hume, D (1748/2008): An Enquiry Concerning Human Understanding. Oxford, UK. Oxford University Press.

Jack, G. (2012): 'Ecological Perspective' in M. Gray, J. Midgley and S.A Webb (eds)The SAGE Handbook of Social Work (pp 129-142) London, UK. Sage.

Jackson, N (2014): 'Common-Sense and Pragmatism: Reid and Peirce on the Justification of First Principles', The Journal of Scottish Philosophy, 12(2), 163-179.

James, W (1909): The Meaning of Truth: A Sequel to 'Pragmatism'. London, UK. Dover Publications.

James, W (1977): The Writings of William James: A Comprehensive Edition. Edited by J.J McDermott. Chicago, USA. Chicago University Press.

Joas, H (1996): The Creativity of Action. Cambridge, UK. Polity Press.

Jordan, B and Drakeford, M (2012): Social Work and Social Policy under Austerity. Basingstoke, UK. Palgrave Macmillan.

Jordan, B (2008): Welfare and Well-Being: Social Value in Public Policy. Bristol, UK. Policy Press.

Jordan, B with Jordan, C (2000): Social Work and the Third way: Tough Love as Social Policy. London. Sage.

Julkunen, I (2011): 'Critical Elements in Evaluating and Developing Practice in Social Work: An Exploratory Overview', Social Work and Social Sciences Review, 15(1), 74-91.

Julkunen, I., Austin, M. J., Fisher, M., \&Uggerhøj, L. (2014). 'Helsinki Statement on Social Work Practice Research', Nordic Social Work Research, 4 (Suppl. 1), 7-13. doi:10.1080/2156857X.2014.981426

Julkunen, I \& Karvinen-Niinikoski, S: (2014) Editorial, Nordic Social Work Research, 4:sup1, 1-6, DOI: $10.1080 / 2156857$ X.2014.985460

Kaidesoja, T. (2013). Naturalizing Critical Realist Social Ontology. London, UK. Routledge.

Kant, I (1787/2004): Critique of Practical Reason (Trans. Abbott). New York, USA. Dover Publications.

Kelp, C., 2016. Justified Belief: Knowledge First Style. Philosophy and Phenomenological Research. DOI: $10.1111 /$ phpr.12272.

Kempson, R.M (1975): Presupposition and the Delimitation of Semantics. Cambridge, UK. Cambridge University Press.

Kinsella, E.A and Pitman, A (Eds) (2012): Phronesis as Professional Knowledge: Practical Wisdom in the Professions. Rotterdam, NL. Sense Publishers.

Kivinen, O and Piiroinen, T (2004): 'The Relevance of Ontological Commitments in Social Sciences: Realist and Pragmatist Viewpoints', Journal for the Theory of Social Behaviour, 34(3), 231-248.

Kjørstad, M (2008): 'Opening the Black Box - Mobilizing Practical Knowledge in Social Research', Qualitative Social Work, 7(2), 143-161.

Knight, K (2007): Aristotelian Philosophy: Ethics and Politics from Aristotle to MacIntyre. Cambridge, UK. Polity Press.

Knorr-Cetina, K. (1999): Epistemic Cultures: How the Sciences Make Knowledge. Cambridge, MA, USA. Harvard University Press.

Koons, J.R (2009): Pragmatic Reasons: A Defense of Morality and Epistemology. Basingstoke, UK. Palgrave Macmillan.

Kothari, A., Rudman, D., Dobbins, M., Rouse, M., Sibbald, S., and Edwards, N (2012): The use of tacit and explicit knowledge in public health: a qualitative study. Implementation Science 7, 20.

Kuhn, T (1970): The Structure of Scientific Revolutions ( $2^{\text {nd }}$ revised edition). Chicago, USA. University of Chicago Press.

Laming, H. (2003): The Victoria Climbie Inquiry. London, UK. The Stationery Office. 
Laming, H (2009): The Protection of Children in England: A Progress Report. London, UK. The Stationery Office.

Lange, M (2008): 'Hume and the Problem of Induction' in D. Gabbay, S. Hartmann and J. Woods (Eds) Handbook of the History of Logic: Volume 10: Inductive Logic. Oxford, UK. North Holland. pp 43-91.

Laudan, L (1990): 'Demystifying Underdetermination', Minnesota Studies in the Philosophy of Science, $14,267-297$.

Leonard, P (1997): Postmodern Welfare: Constructing an Emancipatory Project. London, UK. Sage.

Lipton, P (2004): Inference to the Best Explanation ( $\left.2^{\text {nd }} \mathrm{ed}\right)$. Abingdon, UK. Routledge.

Longhofer, J and Floersch, J (2012): The Coming Crisis in Social Work: Some thoughts on Social Work and Science. Research on Social Work Practice 22, 499-519.

Lorenz, W (2006): Perspectives on European Social Work: From the Birth of the Nation State to the Impact of Globalisation. Opladen, Germany. Barbara Budrich.

Lorenz, W (2012): 'Hermeneutics and Accountable Practice: Lessons from the History of Social Work', Research on Social Work Practice, 22(5), 492-498.

Lorenz, W (2016): 'Reaching the Person-Social Work Research as Professional Responsibility', European Journal of Social Work 19 (3-4), 455-467.

Luitgarden, van de, G.M.J (2009): 'Evidence-Based Practice in Social Work: Lessons from Judgement and Decision-Making Theory', British Journal of Social Work, 39, 243-260.

Lundestad, E (2008): 'The necessity of Pragmatism: Overcoming the Stalemate of Common-Sense', The Journal of Scottish Philosophy, 6(2), 175-187.

McCaffrey, J.F (1981) 'Thomas Chalmers and Social Change', The Scottish Historical Review, 60 (169), 32-60.

Magnus, P.D (2004): 'Reid's Dilemma and the Uses of Pragmatism', The Journal of Scottish Philosophy, 2(1), 69-72.

Manfredo, M. J., Teel, T. L., Gavin, M. C., and Fulton, D. (2014): 'Considerations in Representing Human Individuals in Social-Ecological Models' in Manfredo, M.J., Vaske, J.J., Rechkemmer, A and Duke, E.A (eds) Understanding Society and Natural Resources (pp. 137-158). International Association for Society and Natural resources. London, UK. Springer.

Mäntysaari, M (2005): 'Realism as a Foundation for Social Work Knowledge', Qualitative Social Work, 4(1), 87-98.

Marsh, J.C (2012): From Fish to Bicycles to a Science of Social Work. Research on Social Work Practice, $22,465-467$.

Martela, F (2015): 'Fallible Inquiry with Ethical Ends-in-View: A Pragmatist Philosophy of Science for Organizational Research', Organizational Studies DOI: 10.1177/0170840614559257.

McKenna, R., 2015. 'Epistemic Contextualism Defended', Synthese, 192(2), 363-383.

Mead, G.H (1967): Mind, Self and Society: From the Standpoint of a Social Behaviourist. Chicago, USA. Chicago University Press.

Medina, J (2004): 'In Defense of Pragmatic Contextualism: Wittgenstein and Dewey on Meaning and Agreement', Philosophical Forum, 35(3), 341-369.

Melnyk, B. M., \& Newhouse, R. (2014): Evidence based Practice Versus Evidence informed Practice: A Debate That Could Stall Forward Momentum in Improving Healthcare Quality, Safety, Patient Outcomes, and Costs. Worldviews on Evidence Based Nursing, 11, 347-349.

Milton, S.K (2006): 'Ontology as Meta-Theory: A Perspective', Scandinavian Journal of Information Systems, 18(1), 85-94. :

Mitchell, F., Shaw, I.F. and Lunt, N (2008): Practitioner Research in Social Services: A Literature Review. Dundee, UK. IRISS.

Mullaly, B (2007): The New Structural Social Work (3 $3^{\text {rd }}$ ed). Ontario, Canada. Oxford University Press.

Munro, E (2011): The Munro Review of Child Protection: Final Report: A Child-Centred System. London, UK. Department for Education. 
Nevo, I and Slonim-Nevo, V (2011): 'The Myth of Evidence-Based Practice: Towards Evidence-Informed Practice', British Journal of Social Work, 41, 1176-1197.

Nietzsche, F (1913/1996): On the Geneology of Morals: A Polemic. By way of Clarification and Supplement to my Last Book 'Beyond Good and Evil'. [Trans. Smith). Oxford. Oxford Classics.

Noordegraaf, M and Abma, T (2003): Management by Measurement? Public Management Practice Amidst Ambiguity. Public Administration, 81, 853-871.

Orlikowski, W (2006): 'Material Knowing: The Scaffolding of Human Knowledgeability. European Journal of Information Systems, 15, 460-466.

Orme, J., \& Briar-Lawson, K. (2010). Theory and knowledge about social problems to enhance policy development. The Sage Handbook of Social Work Research, Thousand Oaks, CA, Sage Publications, 98112.

Paavola, S and Hakkarainen, K (2005): 'The Knowledge Creation Metaphor: An Emergent Epistemological Approach', Science and Education, 14, 535-557.

Parton, N (Ed) (1996): Social Theory, Social Change and Social Work. London, UK. Routledge.

Parton, N. (1998). Advanced liberalism, (post) modernity and social work: Some emerging social configurations. Social Thought, 18(3), 71-88.

Parton, N (2000): 'Some thoughts on the relationship between theory and practice in and for social work', British Journal of Social Work, 30, 449-463.

Payne, M (2001): 'Knowledge Bases and Knowledge Biases in Social Work', Journal of Social Work, 1(2), $133-46$.

Payne, M (2005): The Origins of Social Work: Continuity and Change. Basingstoke, UK. Palgrave Macmillan.

Payne, M (2014): Modern Social Work Theory. Basingstoke, UK. Palgrave Macmillan.

Peirce, C.S (1877): 'The Fixation of Belief', Popular Science Monthly, 12 [November], 1-15.

Peirce, C.S (1905): 'What Pragmatism Is', The Monist, 15, 161-181.

Petersén, A.C and Olsson, J.I (2014): 'Calling Evidence-Based Practice into Question: Acknowledging Phronetic Knowledge in Social Work' in British Journal of Social Work doi: 10.1093/bjsw/bcu020.

Philp, M (1979): 'Notes on the form of knowledge in social work', Sociological Review, 27(1, 83-111.

Piaget, J (1953): The Origin of Intelligence in the Child. London, UK. Routledge and Kegan Paul.

Pierson, J (2011): Understanding Social Work: History and Context. Maidenhead, UK. Open University Press/McGraw Hill.

Plath, D (2014): 'Implementing Evidence-based Practice: An Organisational Perspective', British Journal of Social Work, 44, 905-923.

Polkinghorne, J (2002): Quantum Theory: A Very Short Introduction. Oxford, UK. Oxford University Press.

Popper, K (1935/2002a): The Logic of Scientific Discovery. Abingdon, UK. Routledge Classics.

Powell, T.C., 2001. Competitive advantage: logical and philosophical considerations. Strategic management journal, 22(9), 875-888.

Pratt, S.F (2016): 'Pragmatism as Ontology, Not (Just) Epistemology: Exploring the Full Horizon of Pragmatism an Approach to IR Theory', International Studies Review, Advance Access, DOI: 10.1093/ isr/viv003, 1-20.

Pritchard, D (2009): Knowledge. Basingstoke, UK. Palgrave Macmillan.

Prus, R.C and Puddephatt, A.J (2009): 'American Pragmatism: Examining Everyday Life in the Making' in M.H Jacobsen (Ed) Encountering the Everyday: An Introduction to the Sociologies of the Unnoticed. Chapter 2. Basingstoke, UK. Palgrave Macmillan pp 69-92.

Pynn, G (2015): 'Pragmatic Contextualism', Metaphilosophy, 46(1), 26-51.

Quine, W.V.O (1960): Word and Object. Massachusetts, USA. The MIT Press.

Rasmussen, T (2011): 'Knowledge production and Social Work: Forming Knowledge Production', Social Work and Social Sciences Review 15(1), 28-48.

Reid, T (1764/2000): An Inquiry into the Human Mind: On the Principles of Common Sense [Edited by D.R Brookes and K. Haakonssen]. Edinburgh, UK. Edinburgh University Press. 
Reisch, M and Jani, J.S (2012): 'The New Politics of Social Work Practice: Understanding Context to Promote Change', British Journal of Social Work, 42, 1132-1150.

Rescher, N (1994): A System of Pragmatic Idealism: Volume III - Metaphilosophical Inquiries. Princeton, NJ. Princeton University Press.

Rescher, N (2008): Epistemic Pragmatism and Other Studies in the Theory of Knowledge. Heusenstamm, DDR. Ontos Verlag.

Rodger,J.J (2000): From a welfare state to a welfare society: the changing context of social policy in a postmodern era. Basingstoke, UK. Palgrave Macmillan.

Rorty, R. (1991): Objectivity, Relativism, and Truth: Philosophical Papers (Vol. 1). Cambridge, UK. Cambridge University Press.

Rosen, A (1994): 'Knowledge Use in Direct Practice', Social Service Review, 68(4), 561-577.

Rosiek, JL and Pratt, S (2013): 'Jane Addams as a Resource for Developing a Reflexively Realist Social Science Practice', Qualitative Inquiry, 19(8), 578-588.

Rutter, D and Fisher, M (2013): Knowledge Transfer in Social Care and Social Work: Where's the Problem? Kent, UK. Personal Social Services Research Unit (PSSRU).

Ryle, G (1949): The Concept of Mind. London, UK. Hutchinson.

Sackett, D.L., Rosenberg, W.M.C., Gray, J.A.M., Haynes, R.B and Richardson, W.S (1996): 'Evidence Based Practice: What it is and what it isn't', British Medical Journal, 312, 71-2.

Salisbury Forum Group (2011): 'The Salisbury Statement', Social Work and Society, 9(1).

Saurama, E and Julkunen, I (2011): 'Approaching Practice research in Theory and Practice', Social Work and Social Sciences Review, 15(2), 57-75.

Schlagel, R.H (1984): 'A Reasonable Reply to Hume's Scepticism', The British Journal for the Philosophy of Science, 35(4), 359-374.

Schatzki, T (1996): Social Practices: A Wittgensteinian Approach to Human Activity and the Social. Cambridge, UK. Cambridge University Press.

Schön, D (1983): The Reflective Practitioner: How Professionals Think in Action. New York, USA. Basic Books.

Schön, D (2001): 'The Crisis of Professional Knowledge and the Pursuit of an Epistemology of Practice', in J. Raven and J. Stephenson (eds) Competence in the Learning Society. London, UK. Peter Lang. Chapter 13 pp 185-207.

Searle, J.R (1995): The Construction of Social Reality. Harmondsworth. Penguin.

Searle, J.R (1998): 'Social Ontology and the Philosophy of Society', Analyse \& Kritik, 20, 143-158.

Searle, J.R (2006): 'Social Ontology: Some Basic Principles', Anthropological Theory 6(1), 51-71.

Shank, G (1998): 'The Extraordinary Ordinary Powers of Abductive Reasoning', Theory and Psychology, 8(6), 841-860.

Shaw, I (2014): A Science of Social Work? A Response to John Brekke. Research on Social Work Practice, 24, 524-526.

Shaw, S (2016): Review into the welfare in detention of vulnerable persons: a report to the Home Office. London, UK. The Stationery Office.

Sheldon, B., \& Macdonald, G. M. (1999). Research and practice in social care: Mind the gap. Exeter, UK: University of Exeter, Centre for Evidence-Based Social Services.

Sheldon, B. (2001). The validity of evidence-based practice in social work: A reply to Stephen Webb. The British Journal of Social Work, 31(5), 801-809.

Sheppard, M (1995): 'Social Work, Social Science and Practice Wisdom', British Journal of Social Work, 25, 265-94.

Sheppard, M (1998): 'Practice Validity, Reflexivity and Knowledge for Social Work', British Journal of Social Work, 28(5), 763-81.

Sheppard, M and Ryan, K (2003): 'Practitioners as Rule-Using Analysts: A Further Development of Process Knowledge in Social Work', British Journal of Social Work, 33(2), 157-76. 
Shields, P (2003): 'The Community of Inquiry: Classical Pragmatism and Public Administration', Administration and Society, 35(5), 350-58.

Shook, J.R and Margolis, J (Eds) (2009): A Companion to Pragmatism. London, UK. Blackwell.

Shotter, J and Tsoukas, H (2014a): 'Performing Phronesis: On the Way to Engaged Judgement', Management Learning, 45(4), 377-396.

Shotter, J and Tsoukas, H (2014b): 'In Search of Phronesis: Leadership and the Art of Judgement', Academy of Management, Learning and Education, 13(2), 224-243.

Simplican, S. C., Leader, G., Kosciulek, J., and Leahy, M. (2015): 'Defining Social Inclusion of People with Intellectual and Developmental Disabilities: An Ecological Model of Social Networks and Community Participation', Research in Developmental Disabilities, 38, 18-29.

Skaerbaek, E (2010): 'Undressing the Emperor? On the Ethical Dilemmas of Hierarchical Knowledge', Journal of Interprofessional Care, 24(5), 579-586.

Slater, T (2012): 'The Myth of 'Broken Britain': Welfare Reform and the Creation of Ignorance', Antipode, doi: 10.1111/anti.12002.

Smith, S.R (Ed) (2007): Applying Theory to Policy and Practice: Issues for Critical Reflection. Aldershot. Ashgate.

Sommerfeld, P (Ed) (2005): Evidence-Based Social Work: Towards a New Professionalism? Bern, CZ. Peter Lang.

Sommerfeld, P (2014): Social Work as an Action Science: A Perspective from Europe. Research on Social Work Practice, 24, 586-600.

Soydan, H (1999): The History of Ideas in Social Work. Birmingham, UK. Venture Press.

Soydan, H and Palinkas, L.A (2015): Evidence-Based Practice in Social Work: Development of A New Professional Culture. London. Routledge.

Stanley, J. (2007): 'Précis of Knowledge and Practical Interests', Philosophy and Phenomenological Research, $75,168-172$

Stevenson, O (1971): 'Knowledge for Social Work', British Journal of Social Work, 1(2), 225-237.

Taleb, N (2007): The Black Swan. London, UK. Random House Publishing.

Talisse, R. B., and S. F. Aikin (2008): Pragmatism: A Guide for the Perplexed. London, UK. Continuum.

Tavory, I and Timmermans, S (2014): Abductive Analysis: Theorizing Qualitative Research. London, UK. University of Chicago Press.

Thayer, H.S (1980): Meaning and Action: A Critical History of Pragmatism ( $2^{\text {nd }}$ ed). Mimmeapolis, USA. Hackett Publishing.

Thomas, G (2010): 'Doing Case Study: Abduction Not Induction, Phronesis Not Theory', Qualitative Inquiry, 16(7), 575-582.

Toulmin, S (1958): The Uses of Argument. Cambridge, UK. Cambridge University Press.

Tuomela, R. (2013). Social Ontology: Collective intentionality and group agents. Oxford University Press.

Turri, J (2011): 'Manifest Failure: The Gettier Problem Solved', Philosopher's Imprint, 11(8), 1-11.

Turri, J., 2015. Unreliable knowledge. Philosophy and Phenomenological Research, 90(3), 529-545.

Uggerhøj, L (2011): 'Theorizing Practice Research in Social Work', Social Work and Social Sciences Review, $15(1), 49-73$.

Uggerhøj, L (2014): 'Learning from each other: collaboration processes in practice research', Nordic Social Work research, 4, Suppl, 44-57.

Ulrich, W (2007): 'Philosophy for Professionals - Towards Critical Pragmatism', Journal of the Operational Research Society, 58(8), 1109-1113.

Vahid, H (2005): Epistemic Justification and the Skeptical Challenge. Basingstoke, UK. Palgrave Macmillan.

Webb, S (2001): 'Some Considerations on the Validity of Evidence-Based Practice in Social Work', British Journal of Social Work, 31, 57-79.

Weinberg, F.J (2015): 'Epistemological Beliefs and Knowledge Sharing in Work Teams', The Learning Organization, 22(1), 40-57. 
Witkin, S.L (2011): 'Why Do We Think Practice Research is a Good Idea? Comments and Musings Inspired by the Salisbury Statement', Social Work and Society, 9, 10-19.

Witkin, S.L and Harrison, W.D (2001): 'Whose Evidence and For What Purpose? Social Work, 46(4), 293-296.

Wiley, J (2012): Theory and Practice in the Philosophy of David Hume. Basingstoke, UK. Palgrave Macmillan. Wittgenstein, L (1969): On Certainty. Translated by G.E.M Anscombe and G.H von Wright (Eds). New York, USA. Harper \& Row.

Wormer, K van (2007): Human Behaviour and the Social Environment: Micro Level-Individuals and Families. Oxford, UK. Oxford University Press.

Zagzebski, L (1999): 'What is Knowledge?' in J. Greco and E. Sosa (Eds) The Blackwell Guide to Epistemology. Oxford, UK. Blackwell pp92-116.

Znaniecki, F (1934): The Method of Sociology. New York, USA. Farrar and Rinehart. 